International Journal of Engineering \& Technology, $7(2.34)(2018) 22-28$
International Journal of Engineering \& Technology
SPC
Website: www.sciencepubco.com/index.php/IJET
Research paper

\title{
A Conceptual Framework Explaining the Impact of Perceived Career Growth and Organisational Justice on Intention to Stay Among City Traffic Police Lahore
}

\author{
Sultan Adal Mehmood ${ }^{1 *}$, Devika Nadarajah ${ }^{1}$, Muhammad Saood Akhtar ${ }^{1}$, Noor Ahmed Brohi ${ }^{1}$, \\ Mansoor Ahmed Khuhro ${ }^{1}$ \\ ${ }^{\text {I} P u t r a ~ B u s i n e s s ~ S c h o o l, ~ U n i v e r s i t i ~ P u t r a ~ M a l a y s i a, ~ S e r d a n g ~ D a r u l ~ E h s a n ~ S e l a n g o r ~ 43400, ~ M a l a y s i a . ~}$ \\ *Corresponding author E-mail: adilrao01@gmail.com
}

\begin{abstract}
This paper presents the conceptual framework of intention to stay among City Traffic Police, Lahore. The high turnover rate among city traffic police officers in Lahore has drawn the attention of the Government as well as academicians. It is believed that city traffic police in Lahore may feel there is limited prospects of career growth and may have negative perceptions on organisational justice. Nevertheless, this has yet to be examined in greater detail. Therefore, this conceptual paper offers a research opportunity to study the impact of perceived organisational justice and career growth on officer's intention to remain in the organisation. Social exchange theory is applied to this framework. Following this conceptual paper, a full study will be carried out using quantitative research methods. It is hoped that the findings will benefit the City Traffic in Lahore and contribute to the body of knowledge on social exchange theory.
\end{abstract}

Keywords: Organizational Justice, Career growth, Intention to stay, Social Exchange Theory

\section{Introduction}

Employees retention has become a momentous challenge especially in law enforcement agenciesi. The turnover of 1145 out of 3000 officers from City Traffic Police, Lahore in 10 yearsii attracts the attention of this issue in this research.

Various reasons justify why dealing with employee turnover is important for organisations and researchers: Firstly, a number of financial costs is incurred from hiring and training new staff have been identifiediii . First, to be certified as a sworn police officer, one is required to go through a number of specialised training courses, thus making it impracticable to induct fully trained sworn officers directly from the general publiciv. Though Police recruits are paid during their training and certification period, without being able to provide service to the publicv, make them a liability Second, the productivity and performance deficits vi ; In 2006, more than 3300 young graduates were introduced in the Lahore traffic police as traffic wardens to redirect police culture and to replace with public friendly policing. Initially, they performed up to expectations but over the time, they adopted various counterproductive behaviours that are a clear evidence of their waning performance vii . Thirdly, the loss of organisational and jobspecific knowledge; viii 'ix; As public dealing and traffic management is tasks requiring skills, It takes time for a replaced officer to be a veteran in these skills and thus results in reduced performance. Last is the employee's demoralisationx. The morale of traffic wardens are dwindling as a majority of them had quit their service because of discriminatory penalties. According to a Psychologist report lack of (an effective) service structure had abated the morale of traffic wardens. "Rewarding them with certif- icates and cash prizes motivates them for some time. Promoting officers for good work can be a permanent force of motivation"xi . According to the rules of the Punjab Traffic Warden Service Rules 2007, every warden was to be promoted following the completion of five years of service. Several wardens reported that lack of promotion opportunities was the chief reason for the high turnoverxii.

Unlike the past, career and job shifting is increasingxiii . High employee turnover is becoming a crucial issue in public organisationsxiv. Police work is considered as one of the most taxing occupations in the worldxv . To help police officers cope with their stressful roles, it is important to take measures that may increase their intention to stayxvi. Therefore, turnover issue is catching the interest of Western scholars and practitionersxvii. Intention to stay which, reduces employee turnover, intensifies with high career growth opportunitiesxviii and organisational justicexix. J. Liu, Yang, Liu, Yang, \& Zhang, (2015)xx investigated the impact of organisational work, support and career growth on nurse turnover intention in China.

Despite significant implications and the potential to prevent voluntary turnover, there has been limited research into the nature of turnover in police organisationsxxi. In particular, very less work in this regard has been done on policing in the Pakistani context. Hence, this research is intended to examine empirically the impact of perceived career growth and organisational justice on intentions of those who are still working in City Traffic Police, Lahore (CTPL) . Also, to what extent these two factors contribute to their turnover and what possibly can be done to nourish their intention to stay. 


\section{Objectives of the study}

As high turnover rates cause serious performance problems in the public agency like Police, this study considers the importance of organisational justice and employees' perceived career growth on intention to stay. It is assumed that organisational justice and perceived career growth will play a vital role in the whole process, affecting turnover and turnover intentions. The study has two specific objectives:

1. To examine the impact of organisational justice on employees intention to stay in City Traffic Police, Lahore.

2. To examine the influence of employee's perceived career growth on their intentions to stay in City Traffic Police, Lahore.

\section{Literature review}

\subsection{Social exchange theory}

Social Exchange theory supports the proposed relationship of intention to stay (ITS) with organisational justice and perceived career growth. In this theory Blauxxii (1964) put into words social exchanges as 'voluntary actions' in response of an organisation's treatment of its employees, expecting such treatment will give back in the long run. Initially developed to examine the interpersonal relationship, Social Exchange Theory (SET) has widely been applied to explain the nature of employee employer relationshipxxiii. Social exchange relationships develop when an organisation shows concern for its employees. It usually results in favourable consequences for the organisationxxiv. In other words, employee's productive attitudes and behaviours are a result of positive social exchange relationships.

Social exchange theory postulates that employees are more committed to their organisation and job when they perceive fair and balanced system of exchangexxv. In ideal workplace conditions, employees perceive high levels of support from the organisation, supervisors and colleagues, and therefore, reciprocate with positive actions and perceptions about the organisationxxvi. If an employee perceives that the organisation has benefited from their part of the exchange and this benefit is not reciprocated within an appropriate time, as expected by the employee, this may have a detrimental effect on the growth of the relationship xxvii, xxviii. With regards to a fair social exchange experience with their organisations, employees may infer that they are valued and trusted by their organisations and thus may be more willing to return their employer's expectations by displaying positive attitudes xxix While applying this theory in police organisation, a police officer will show concerns for his organisation where he perceives support especially in terms of fair treatment. Conversely, the officer may reduce productivity to seek alternative employment opportunity.

\subsection{Intention to stay}

According to Cotton \& Tuttlexxx (1986), intentions to stay (ITS) is an employee's perceived probability of staying in current organization. Similarly, Hom \& Griffethxxxi (1991) referred to it as the strength of a person's relative intent toward discretionary and permanent discontinuation from the employment. Intention to stay predicts retention and contrary to its intention to leave predicts turnover of employeesxxxii. In some research turnover intention is an essential root of real rate of employee's withdrawal and in others, it is the actual outcomexxxiii. March \& Simon,xxxiv (1958) took it in another dimension; according to them, intention to stay or quit is dependent on the strength of desire for the job and easiness of movement in terms of switching the job. Moreover, desirability is determined by internal factors related to job satisfaction that is associated with job embeddedness and ease of movement is determined by options available to the employee other than current employment.
Intention to stay positively correlates with the level of job satisfaction. Numerous studies support it with the argument that dissatisfied employees are relatively more prone to quitting their current employment than satisfied employeesxxxv. An employee's level of job satisfaction is predominantly related to an individual's attitude toward the job whether it is rewarding enough to continue doing itxxxvi. More precisely in the case of police work, job satisfaction is negatively associated with job-related stressors as Yun,xxxvii Hwang, \& Lynch, (2015) demonstrated this relationship in a research on Korean police officers which further suggests that employees intention to stay can be increased by applying mediating factors on work stressors and burnout. Whereas Adebayo \& Ogunsina, xxxviii (2011) suggested that supervisory behaviour is a chief cause of stress among police personnel in Nigeria. Brough \& Frame,xxxix (2004) examined social support as a predictor of stress and job satisfaction that ultimately shakes intention to stay among police personnel. This study addresses the relationship of colleagues and supervisors in terms of social support and focuses on harassment issues especially among female employees.

Research also links compensation with the intention to stay. Dissatisfaction in terms of salary package leads toward turnover. Contrary to it, competitive salary package helps keep the employee motivated hence intensifies their intention to stayxl . Usually, dirty work pays well because the appeal of money motivates employees to tradeoff with dirty, dangerous and morally tainted jobs. Same analogy applies on police as their nature of work is considered dirty in most of the casesxli. The absence of a benefit package can increase the employee's likelihood to think about other job opportunities. A commitment model developed by Kiekbusch, Price, \& Theis,xlii (2010) based partially on job benefits, reveals that the absence of sufficient benefits is one of the main factors coming up with employee turnover. Moreover, individuals who experience conflict between their professional and organization values are more likely to quit, while those who find a good fit between it tend to stay longerxliii.

Supervisory behaviour has profound implication on the intention to stay as is evident in the research of Adebayo,xliv (2011) that was conducted on police employees in Nigeria. That implies, democratic nature of work practice can strengthen the intention to stay. Since police leadership has best suited to the autocratic style, subordinates were prone to stress and strainxlv. Research also revealed that service period may affect turnover intention, implies that senior employees are more immune to turnover intention as compared to newcomers. However, Drewxlvi 2008 suggested that personality trait of individual may intervene as a mediating factor. Interpersonal relations in employment determine the level of satisfactionxlvii (Griffeth, 1995). Similar studies show that relatedness feeling toward coworker might motivate employees and, in turn, affects well-being, job satisfaction and turnover. X. Hu, Kaplan, \& Dalal,xlviii (2010) extended this idea on nature of work and established that blue collar workers develop closer relationship with their colleagues than white collars. As a result of it, blue collar workers prefer their relationship to the quality of work of their coworkers.

Barrick \& Zimmerman, (2005)xlix summarized that pre hire dispositions, behavioral intentions and attitudes envisage voluntary turnover. Prospective employees may be predisposed to quitting the organization in a short time for many reasons. In these instances, applicants may be intending to find a more permanent career once they finish education or they may be biding their time until a more suitable job appears.

There are studies which suggest that workplace stress has its role in turnover intentions 1. Podsakoff, (2007) li identified work stressors as those criteria which positively or negatively affect employee retention. Positive or challenge-related stressors are labeled as those which inspire challenge among employees such as greater responsibility and working under time constraints. Employees perceive these as potentially promoting personal growth and achievement. By meeting the expectations of their superiors and accomplishing assigned tasks, employees showed more lon- 
gevity and fewer propensities for turnover. In contrast, negative or hindrance-related stressors are identified as job ambiguity, organizational politics, and concerns about job security. Job ambiguity is cited as the absence of clear, consistent information about the set of expected job functions and has been identified as one of the first possible indicators of turnoverlii. Organizational politics are defined by popularity and favoritism. Consequently, employees are apt to identify these negative stressors as potentially hindering their personal development, work- related accomplishments, and opportunities for growth or promotion. Kiekbusch et al., (2010)liii found that negative stressors are related to a decrease in job satisfaction and an increase in job search behaviors and turnover.

Overall, turnover has a detrimental effect on police organizations. This ill effect can be in the form of direct or indirect costs. Direct costs are associated with recruitment, selection, training, overtime, and other monetary figures. Indirect costs include the disruption in police service to the community and a decline in agency morale. The general organizational literature identifies numerous factors that contribute to employee turnover including job dissatisfaction, low organizational commitment, stress, lack of social support, inadequate supervision and leadership, low pay, and insufficient trainingliv 'lv 'lvi 'lvii.

Literature that has focused specifically on retention and turnover within the law enforcement profession suggests that job dissatisfaction and shortcomings within the organization contribute to police turnoverlviii. Still other researchers suggest that inconsistencies between expectations of the job and the reality of police work, as well as lack of opportunities for career advancement are factors that cause officers to leave the joblix.

Although there is some research on the role of job expectations, there is very limited identifiable studies which examine how career development opportunities, or the lack thereof, influence turnover within small police agencies.

\subsection{Organisational justice}

For building up trust in workers and employees, the organisation has to take a fair approach in all aspects connected with daily work. Organisational justice is composed of three dimensions: distributive, procedural and interactional justice.

Moorman, (1991)lx expounded this construct with the ways employee determine whether they have been treated fairly in their work and whether those determinations influence other work related attitudes.

The employees in a workplace will focus on fair treatment, which motivates them to keep up the fairness within the relationships between them and the organisation. Researchers have contended that the form of equity in the workplace is based on the ratio of inputs to the outcomes; if employees feel there is any inequity when compared with the others, resentments or unpleasant feelings emergelxi . In a study of health workers in Nigeria, organisational justice was found to have a substantial effect on turnover intentionlxii (Owolabi, 2012). Although different kinds of benefits will help to attract employees to stay in an organisation with a positive organisational culture, the primary driver for employee satisfaction and retention is a social environment of justicelxiii (Owolabi, 2012).

\subsection{Interactional justice}

Interactional justice in the workplace is rooted in social exchange theory and the norm of reciprocitylxiv . It also refers to the organisation's concern about the feelings and well-being of employees and with quality treatment when procedures are enforcedlxv . It has two dimensions: informational justice and interpersonal justicelxvi. Informational justice is about actions taken by the management, such as how the information is disseminated to the employees (e.g. listening to the employees' concerns, providing adequate explanations for decision-making, demonstrating care about their well-being). It explains how the information is conveyed and offered to the people. Whereas, Interpersonal justice pertains to personal treatment, such as politeness, respect and dignity. Another study found that employees indicate their concerns about the treatment they receive from an organisation and their participation and the transparency of the procedures of decision-makinglxvii . From the social exchange perspective, employees expect to receive honest, fair, truthful and respectful treatment from their organisation or its representatives. When they receive fair treatment, they will have greater satisfaction with their job. It is essential for management to foster sustainable advantages in the highly competitive world today. Hence, the management of an organisation has to be very informative and respectful to its employees to retain themlxviii. Interactional justice has been found to be negatively related to turnover intentionlxix.

\subsection{Distributive justice}

Distributive justice refers to the fairness of treatment for the rewards they receive, such as pay and promotionslxx. The concept was initially derived from Adams,lxxi who used an equity theory framework to evaluate fairness. Adam,lxxii (1965) asserted that employees use fair treatment as a motivating force to retain fairness within the relationships with their co-workers and the organisation. In other words, the employee will weigh their perceived input and outcome ratio. It is also the perceptions of the employees that their pay and promotions are to be fair compared to their co-workers. If they notice that they are paid inequitably based on the same job specification, then negative feelings will occur. As a result, dissatisfaction and negative effects, such as changing jobs, emerge in the workplacelxxiii, which is in line with Moorman's (1991) statement about organisational justice.

In a study of the significance of organisational justice on turnover decisions, Muzumdar (2012)lxxiv suggested that in a manufacturing industry, it would be useful to count not only the number of parts produced by the workers but also the number of errors committed while the parts were produced. It reflects the factor of the outcome, where fairness such as the reward allocation for the individual's hard work has to be justified regarding the quantity and quality of performance in the workplace. Researchers have also reported that distributive justice is related to trust in an organisation, organisational commitment and other work outcomeslxxv.

\subsection{Procedural justice}

Procedural justice refers to the fairness of the manner in which the decision-making process is conductedlxxvi. Procedural justice was first introduced by Walkerlxxvii in third-party dispute proceedings, such as arbitration and mediation. Procedural justice occurs in a shift in the perception of an individual, from what was decided on to how the decision was madelxxviii. Other studies have revealed a strong relationship between procedural justice and organisational trust, as well as in the outcomes of organisational commitmentlxxix.

\subsection{Career growth}

While 'career' is understood as an individual's succession of work experiences in his lifetimelxxx , 'career growth' is defined as "one's perceptions of the chances of development and advancement within an organisation"lxxxi. Previous research on career growth has investigated aspects such as career self-management and graduates' early experiences in an organisationlxxxii . A survey conducted by Weng \& McElroy (2012)lxxxiii in 176 companies in nine cities of China argued that not much emphasis has been paid to the specific ways in which experienced employees perceive their opportunities for promotion and development in an organisation.

Personal development opportunitylxxxiv, promotion equity and training lxxxv and opportunity for learning affect employees' commitment to organisations. Organisations need to provide advancement for workers in the form of career growth, career development or career success to establish and maintain the attachment 
of employees to the organisationlxxxvi . This may involve promotion or lateral movement to new functions or knowledge and skill development or new assignments within a given area. The development processes must focus on both the organisation's need to fill roles and employees' needs to have some sense of advancement in their work prospectslxxxvii . Surveys conducted by B. Shuck et al., (2014)lxxxviii in China on the career choice of potential employees of several organisations proves that career development is one of the most significant factors in ideal career choice. Other research has indicated that employee perceptions of positive internal career advancement opportunities may lead to low turnover intentionslxxxix .

A survey conducted among managers, professional personnel and technicians in 176 companies in China suggested that employees give positive commitment to employers who back up Human Resource Management (HRM) practices with a competitive reward system such as the opportunity for career growth that reinforces the value of employee contributions to the organisationxc. The study was later supported by Wang, Weng, McElroy, Ashkanasy, \& Lievens, (2014)xci based on a survey among managers in 131 companies operating in China, indicating that career growth has a bearing not only on an employee's own efforts and ability to pursue personal career goals and gain new skills but also on the employer's support in providing incentives for such activities by an increase in organisational rewards. On the other hand, when employees perceive that there is inequity in performance appraisal and compensation, this negative perception leads them to reciprocate in the form of low organisational commitmentxcii . Career growth which includes promotion speed and remuneration growth are linked to performance appraisal. Good performance appraisals from the person responsible for rating an individual employee's performance impact on merit for promotion as well as remuneration growthxciii .

\subsection{Promotion speed}

Seibert, Kraimer, \& Crant, (2001)xciv defined 'promotion' as any increase in level and or any significant increase in job responsibilities or job scope. Promotion speed was described by Dries, Pepermans, \& Carlier, (2008)xcv as the pace at which the employee has climbed the ladder as opposed to stagnating in the same function for long time. Where internal promotion speed appears to match employees' contributions to the success of the organisation, those employees are more likely to be satisfied and develop a sense of belongingxcvi.

\subsection{Career goal progress}

Achieving career goal progress is a typical example of higher order need satisfactionxcvii. The convergence of the employeeemployer relationship correlates to employees feeling more affinity with the organisation and they experience career development when they are in jobs connected to their career goalsxcviii. According Juhdi \& Hashim (2013),xcix in their survey of employees in Malaysian companies, suggested that individuals who perceives they have the relevant educational backgrounds, skills and knowledge of job and company core business tend to be committed to the organisation. A survey of grocery store and hospital employees conducted by (Mitchell \& Lee, 2001)c in the US argued that employees who have knowledge, job skills and abilities which fit their job descriptions may become professionally and personally attached to the organisation.

\subsection{Professional ability development}

Achieving professional ability development in an organisation is also an example of an advanced level of need satisfactionci. The opportunity to gain knowledge in an organisation can be a significant determinant of employees' work-related attitudes and behaviour and their unwritten psychological contract with the employercii. For this study, professional ability development or training is defined as the development of the knowledge, skills and abilities that employees require to perform their tasks competentlyciii. Hackman \& Oldham, (1975)civ argued that experiencing meaningful work is connected to positive satisfaction as well as decreased staff turnover. A survey of nurses in US public hospitals carried out by Bartlett, (2001)cv suggested that the provision of professional ability development might be perceived as a sign that the employer is making an effort to engage in social exchange with employees, and thus might induce reciprocity in terms of the employees strengthening their emotional attachment and feelings of obligation to the organisation.

\subsection{Remuneration growth}

In addition to promotion speed, remuneration growth also provides a measure of how employees are evaluated by employerscvi. Employees expect fair value and return from their employers as referred to psychological contract and balance social exchangecvii. Surveys conducted by Weng and McElroy (2012)cviii in China reported that remuneration growth is positively associated with organisational commitment when employees perceive that their contributions are valued by the employer in terms of remuneration and rewards. Remuneration encompasses fringe benefits, salary and yearly bonuscix . Moreover, Juhdi et al. (2013)cx in their survey among employees of universities, banks, insurance and finance companies in Malaysia and Miao et al. (2013)cxi in their survey among full-time employees of government administration departments in China suggested that remuneration has a positive influence on organisational commitment, as when employees perceive that what they think they should receive is being met by the employer, then organisational commitment tends to increase.

\subsection{Interrelationship among constructs}

Based on social exchange theory and review of the literature, this research conceptualises the following hypothesis in context of City Traffic Police, Lahore:

Based on social exchange theory and review of the literature, this research conceptualises the following hypothesis in context of City Traffic Police, Lahore:

H1: Higher the level of Organisational justice, higher the intention to stay

H1(a): Distributive justice is related to intention to stay

H1(b): Procedural justice is related to intention to stay

H1(c): Interactional justice is related to intention to stay

H2: Higher the level of Perceived Career Growth, Higher the intention to stay

$\mathrm{H} 2$ (a): Career goal progress is related to intention to stay

H2(b): Professional ability development is related to intention to stay

H2(c): Promotion speed is related to intention to stay

$\mathrm{H} 2(\mathrm{~d})$ : Remuneration growth is related to intention to stay

\section{Research framework and design}

This paper intends to propose an appropriate research framework and research design to empirically examine the interaction of various constructs as shown in Figure 1. 


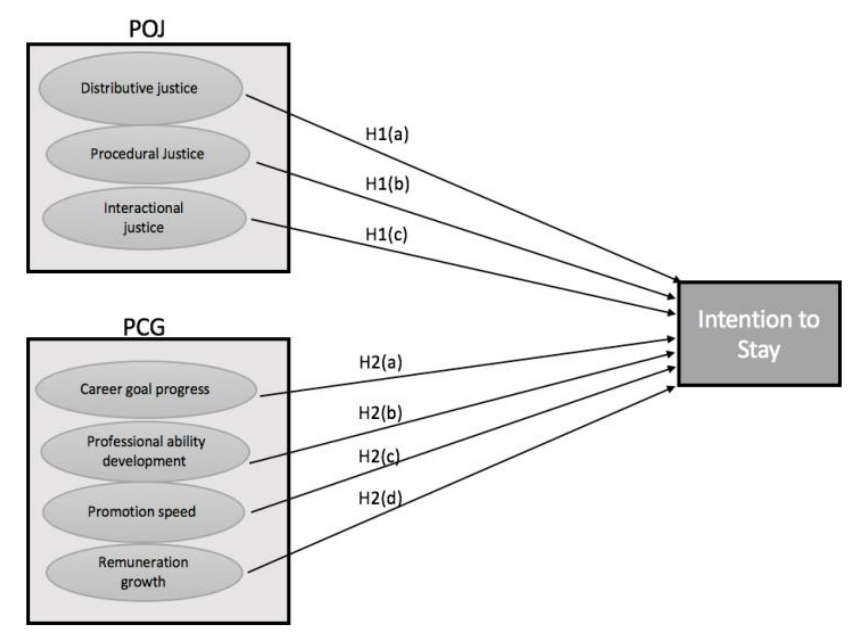

Fig. 1

\section{Conclusions and future recommendation}

The primary objective of this study is to determine the factors that significantly contribute in understanding the behaviour of traffic wardens for staying or quitting current job. Results of this study may provide the empirical base in explaining the high turnover in CTPL. Higher police authorities would be able to take corrective measures to increase officer's retention that will ultimately improve their performance. This study will motivate researchers to turn their attention towards traffic police regarding their policy issues, which largely have been neglected. The proposed model can be applied to other departments where turnover is a critical issue. Future research in this area can enrich this framework by adding endogenous and exogenous factors to determine the intention of employees in an organisation.

\section{References}

[1] Hollis, M. E., \& Wilson, J. M. (2015). Police staffing levels: disaggregating the variation. Policing: An International Journal of Police Strategies \& Management, 38(4), 820-839.

[2] Bajwa, A. (2015). Service structure: Regulations sought for warden promotion. The Express Tribune. Retrieved from http://tribune.com.pk/story/907581/service-structure-regulationssought-for-wardens-promotions/

[3] Hom, P. W., Tsui, A. S., Wu, J. B., Lee, T. W., Zhang, A. Y., Fu, P. P., \& Li, L. (2009). Explaining employment relationships with social exchange and job embeddedness. Journal of Applied Psychology, 94(2), 277 .

[4] Lynch, J. E., \& Tuckey, M. (2008). The police turnover problem: fact or fiction? Policing: An International Journal of Police Strategies \& Management, 31(1), 6-18

[5] Marion, N. (1998). Police academy training: are we teaching recruits what they need to know? Policing: An International Journal of Police Strategies \& Management, 21(1), 54-79.

[6] Griffeth, R. W., Hom, P. W., \& Gaertner, S. (2000). A metaanalysis of antecedents and correlates of employee turnover: Update, moderator tests, and research implications for the next millennium. Journal of management, 26(3), 463-488.

[7] Naji, N. (2015). Sawary sawarry. Daily Dunia News, pp. 22.

[8] Griffeth, R. W., Hom, P. W., \& Gaertner, S. (2000). A metaanalysis of antecedents and correlates of employee turnover: Update, moderator tests, and research implications for the next millennium. Journal of management, 26(3), 463-488.

[9] Hom, P. W., Tsui, A. S., Wu, J. B., Lee, T. W., Zhang, A. Y., Fu, P. P., \& Li, L. (2009). Explaining employment relationships with social exchange and job embeddedness. Journal of Applied Psychology, 94(2), 277.

[10] Steers, R. M., Mowday, R. T., \& Shapiro, D. L. (2004). Introduction to special topic forum: The future of work motivation theory. The Academy of Management Review, 29(3), 379-387.

[11] Bajwa, A. (2015). Service structure: Regulations sought for warden promotion. The Express Tribune. Retrieved from http://tribune.com.pk/story/907581/service-structure-regulationssought-for-wardens-promotions/

[12] The Express, (2015). Service structure: Regulations sought for warden promotion. The Express Tribune. Retrieved from http://tribune.com.pk/story/907581/service-structure-regulationssought-for-wardens-promotions/

[13] Weng, Q., \& McElroy, J. C. (2012). Organizational career growth, affective occupational commitment and turnover intentions. Journal of Vocational Behavior, 80(2), 256-265.

[14] Guthrie, J. P. (2001). High-involvement work practices, turnover, and productivity: Evidence from New Zealand. Academy of management Journal, 44(1), 180-190.

[15] Stress in policing. Washington: American Psychological Association. http://doi.org/10.1037/10417-000

[16] Luthans, F., Rhee, S., Luthans, B. C., \& Avey, J. B. (2008). Impact of behavioral performance management in a Korean application. Leadership \& Organization Development Journal, 29(5), 427-443.

[17] Call, M. L., Nyberg, A. J., Ployhart, R. E., \& Weekley, J. (2015) The dynamic nature of collective turnover and unit performance: the impact of time, quality, and replacements. Academy of Management Journal, 58(4), 1208-1232.

[18] Weng, Q., \& McElroy, J. C. (2012). Organizational career growth, affective occupational commitment and turnover intentions. Journal of Vocational Behavior, 80(2), 256-265.

[19] Griffin, B. (2010). Multilevel relationships between organizationallevel incivility, justice and intention to stay. Work \& Stress, 24(4), 309-323.

[20] Yun, I., Hwang, E., \& Lynch, J. (2015). Police stressors, job satisfaction, burnout, and turnover intention among South Korean police officers. Asian Journal of Criminology, 10(1), 23-41.

[21] Markopoulos Jr, W. P. (2017). Perceived Influence of the Ferguson Effect On Law Enforcement Officer Turnover Intentions.

[22] Al Shikhy, A., Makhbul, Z. M., Ali, K. A. M., Al Mazari, A., \& PSCJ, A. 1.1 Room 1 (Jintan)-Session 1: Human Resource Management Modeling the Impact of Resistance to Change within the Context of Human Resources Information Systems Adoption.

[23] Shore, L. M., Coyle-Shapiro, J. A. M., Chen, X. P., \& Tetrick, L. E. (2009). Social exchange in work settings: Content, process, and mixed models. Management and Organization Review, 5(3), 289302.

[24] Cropanzano, R., Slaughter, J. E., \& Bachiochi, P. D. (2005). Organizational justice and black applicants' reactions to affirmative action Journal of Applied Psychology, 90(6), 1168-1184.

[25] Al Shikhy, A., Makhbul, Z. M., Ali, K. A. M., Al Mazari, A., \& PSCJ, A. 1.1 Room 1 (Jintan)-Session 1: Human Resource Management Modeling the Impact of Resistance to Change within the Context of Human Resources Information Systems Adoption.

[26] Xerri, M. J., \& Brunetto, Y. (2013). Fostering innovative behaviour: The importance of employee commitment and organisational citizenship behaviour. The International Journal of Human Resource Management, 24(16), 3163-3177.

[27] Ang, J. B., Banerjee, R., \& Madsen, J. B. (2013). Innovation and productivity advances in British agriculture: 1620-1850. Southern Economic Journal, 80(1), 162-186.

[28] Xerri, M. (2013). Workplace relationships and the innovative behaviour of nursing employees: a social exchange perspective. Asia Pacific Journal of Human Resources, 51(1), 103-123.

[29] Ng, T. W., Lam, S. S., \& Feldman, D. C. (2016). Organizational citizenship behavior and counterproductive work behavior: Do males and females differ?. Journal of Vocational Behavior, 93, 1132.

[30] Cotton, J. L., \& Tuttle, J. M. (1986). Employee turnover: A metaanalysis and review with implications for research. Academy of management Review, 11(1), 55-70.

[31] Hom, P. W., \& Griffeth, R. W. (1991). Structural equations modeling test of a turnover theory: Cross-sectional and longitudinal analyses. Journal of applied psychology, 76(3), 350

[32] Wells, N., Roberts, L., \& Medlin, L. C. (2002, September). Issues related to staff retention and turnover. In Seminars for nurse managers (Vol. 10, No. 3, pp. 171-179).

[33] Lum, L., Kervin, J., Clark, K., Reid, F., \& Sirola, W. (1998). Explaining Nursing Turnover Intent: Job Satisfaction. Pay Satisfaction, or Organizational Commitment.

[34] March, J. G., \& Simon, H. A. (1993). Organizations revisited. Industrial and Corporate Change, 2(3), 299-316.

[35] De Gieter, S., De Cooman, R., Hofmans, J., Pepermans, R., \& Jegers, M. (2012). Pay-level satisfaction and psychological reward satisfaction as mediators of the organizational justice-turnover in- 
tention relationship. International Studies of Management \& Organization, 42(1), 50-67.

[36] Thatcher, J. B., Stepina, L. P., \& Boyle, R. J. (2002). Turnover of information technology workers: Examining empirically the influence of attitudes, job characteristics, and external markets. Journal of Management Information Systems, 19(3), 231-261.

[37] Yun, I., Hwang, E., \& Lynch, J. (2015). Police stressors, job satisfaction, burnout, and turnover intention among South Korean police officers. Asian Journal of Criminology, 10(1), 23-41

[38] Adebayo, S. O., \& Ogunsina, S. O. (2011). Influence of supervisory behaviour and job stress on job satisfaction and turnover intention of police personnel in Ekiti State. Journal of Management and Strategy, 2(3), 13.

[39] Brough, P., \& Frame, R. (2004). Predicting police job satisfaction and turnover intentions: The role of social support and police organisational variables. New Zealand journal of psychology, 33(1), 8-18.

[40] Bryant, P. C., \& Allen, D. G. (2013). Compensation, benefits and employee turnover: HR strategies for retaining top talent. Compensation \& Benefits Review, 45(3), 171-175.

[41] Dick, P. (2005). Dirty work designations: How police officers account for their use of coercive force. Human relations, 58(11) 1363-1390.

[42] Kiekbusch, R., Price, W., \& Theis, J. (2003). Turnover predictors: causes of employee turnover in sheriff-operated jails. Criminal Justice Studies, 16(2), 67-76.

[43] OKalemci Tuzun, I., \& Arzu Kalemci, R. (2012). Organizational and supervisory support in relation to employee turnover intentions. Journal of Managerial Psychology, 27(5), 518-534.

[44] Adebayo, S. O., \& Ogunsina, S. O. (2011). Influence of supervisory behaviour and job stress on job satisfaction and turnover intention of police personnel in Ekiti State. Journal of Management and Strategy, 2(3), 13

[45] Herrington, V. (2016). Police Leadership: An Australasian Commentary.

[46] Drew, J., Carless, S. A., \& Thompson, B. M. (2008). Predicting turnover of police officers using the sixteen personality factor questionnaire. Journal of Criminal Justice, 36(4), 326-331.

[47] Griffeth, R. W., Hom, P. W., \& Gaertner, S. (2000). A metaanalysis of antecedents and correlates of employee turnover: Update, moderator tests, and research implications for the next millennium. Journal of management, 26(3), 463-488.

[48] Hu, X., Kaplan, S., \& Dalal, R. S. (2010). An examination of blueversus white-collar workers' conceptualizations of job satisfaction facets. Journal of Vocational Behavior, 76(2), 317-325.

[49] Barrick, M. R., \& Zimmerman, R. D. (2005). Reducing voluntary, avoidable turnover through selection. Journal of Applied Psychology, 90(1), 159.

[50] Brough, P., \& Frame, R. (2004). Predicting police job satisfaction and turnover intentions: The role of social support and police organisational variables. New Zealand journal of psychology, 33(1), 8-18.

[51] Podsakoff, N. P., LePine, J. A., \& LePine, M. A. (2007). Differential challenge stressor-hindrance stressor relationships with job attitudes, turnover intentions, turnover, and withdrawal behavior: a meta-analysis. Journal of applied psychology, 92(2), 438.

[52] Podsakoff, N. P., LePine, J. A., \& LePine, M. A. (2007). Differential challenge stressor-hindrance stressor relationships with job attitudes, turnover intentions, turnover, and withdrawal behavior: a meta-analysis. Journal of applied psychology, 92(2), 438

[53] Kiekbusch, R., Price, W., \& Theis, J. (2003). Turnover predictors causes of employee turnover in sheriff-operated jails. Criminal Justice Studies, 16(2), 67-76.

[54] Brough, P., \& Frame, R. (2004). Predicting police job satisfaction and turnover intentions: The role of social support and police organisational variables. New Zealand journal of psychology, 33(1), 8-18.

[55] Elçi, M., Erdilek, M. K., Alpkan, L., \& Sener, İ. (2014). The mediating role of mobbing on the relationship between organizational silence and turnover intention. Procedia-Social and Behavioral Sciences, 150, 455-464.

[56] Kiekbusch, R., Price, W., \& Theis, J. (2003). Turnover predictors: causes of employee turnover in sheriff-operated jails. Criminal Justice Studies, 16(2), 67-76.

[57] McNatt, D. B., \& Judge, T. A. (2008). Self-efficacy intervention, job attitudes, and turnover: A field experiment with employees in role transition. Human Relations, 61(6), 783-810.
[58] Wilson, J. M., Dalton, E., Scheer, C., \& Grammich, C. A. (2010). Police recruitment and retention for the new millennium. Santa Monica, CA: RAND Corporation.

[59] Harris, L. M., \& Baldwin, J. N. (1999). Voluntary turnover of field operations officers: A test of confluency theory. Journal of Criminal Justice, 27(6), 483-493

[60] Moorman, R. H. (1991). Relationship between organizational justice and organizational citizenship behaviors: Do fairness perceptions influence employee citizenship? Journal of Applied Psychology, 76(6), 845-855. http://doi.org/10.1037/0021-9010.76.6.845

[61] Organizational justice and human resource management Sage Publications

[62] Owolabi, A. B. (2012). Effect of organizational justice and organizational environment on turn-over intention of health workers in Ekiti state, Nigeria. Research in World Economy

[63] Owolabi, A. B. (2012). Effect of organizational justice and organizational environment on turn-over intention of health workers in Ekiti state, Nigeria. Research in World Economy.

[64] Cropanzano, R., Slaughter, J. E., \& Bachiochi, P. D. (2005). Organizational Justice and Black Applicants' Reactions to Affirmative Action. Journal of Applied Psychology, 90(6), 1168-1184 http://doi.org/10.1037/0021-9010.90.6.1168

[65] Brunetto, Y., Xerri, M., Shriberg, A., Farr Wharton, R., Shacklock, K., Newman, S., \& Dienger, J. (2013). The impact of workplace relationships on engagement, well-being, commitment and turnover for nurses in Australia and the USA. Journal of Advanced Nursing, 69(12), 2786-2799. http://doi.org/10.1111/jan.12165

[66] Colquitt, J. A., Greenberg, J., \& Zapata-Phelan, C. P. (2005). What is organizational justice? A historical overview. Handbook of organizational justice, 1, 3-58.

[67] Bies, R. J., Shapiro, D. L., \& Cummings, L. L. (1988). Causal Accounts and Managing Organizational Conflict Is It Enough to Say It's Not My Fault? Communication Research.

[68] Wood, D. (2001). Police turnover in isolated communities: The Alaska experience. National Institute of Justice Journal.

[69] Muzumdar, P. (2012). Influence of Interactional Justice on the Turnover Behavioral Decision in an Organization

[70] Moorman, R. H. (1991). Relationship between organizational justice and organizational citizenship behaviors: Do fairness perceptions influence employee citizenship? Journal of Applied Psychology, 76(6), 845-855. http://doi.org/10.1037/0021-9010.76.6.845

[71] Adams, J. S., Berkowitz, L., \& Walster, E. (1976). Advances in experimental social psychology. Vol. 9, Equity theory: toward a general theory of social interaction.

[72] Adams, J. S., Berkowitz, L., \& Walster, E. (1976). Advances in experimental social psychology. Vol. 9, Equity theory: toward a general theory of social interaction.

[73] Loi, R., Hang Yue, N., \& Foley, S. (2006). Linking employees' justice perceptions to organizational commitment and intention to leave: The mediating role of perceived organizational support. Journal of Occupational and Organizational Psychology, 79(1), 101-120. http://doi.org/10.1348/096317905X39657

[74] Muzumdar, P. (2012). Influence of Interactional Justice on the Turnover Behavioral Decision in an Organization.

[75] Loi, R., Hang Yue, N., \& Foley, S. (2006). Linking employees' justice perceptions to organizational commitment and intention to leave: The mediating role of perceived organizational support. Journal of Occupational and Organizational Psychology, 79(1), 101-120. http://doi.org/10.1348/096317905X39657

[76] Folger, R. G., \& Cropanzano, R. (1998). Organizational justice and human resource management (Vol. 7). Sage.

[77] Thibaut, J. W., \& Walker, L. (1975). Procedural justice: A psychological analysis. L. Erlbaum Associates.

[78] Cropanzano, R., Slaughter, J. E., \& Bachiochi, P. D. (2005). Organizational Justice and Black Applicants' Reactions to Affirmative Action. Journal of Applied Psychology, 90(6), 1168-1184. http://doi.org/10.1037/0021-9010.90.6.1168

[79] Newman, A., Thanacoody, R., \& Hui, W. (2011). The effects of perceived organizational support, perceived supervisor support and intra-organizational network resources on turnover intentions. Personnel Review, 41(1), 56-72. http://doi.org/10.1108/00483481211189947

[80] Arthur, M. B., DeFILLIPPI, R. J., \& Lindsay, V. J. (2008). On being a knowledge worker. Organizational Dynamics, 37(4), 365-377.

[81] Jans, N. A. (1989). Organizational commitment, career factors and career/life stage. Journal of Organizational Behavior, 10(3), 247 266. http://doi.org/10.1002/job.4030100305 
[82] Sturges, J., Guest, D., Conway, N., \& Davey, K. M. (2002). A longitudinal study of the relationship between career management and organizational commitment among graduates in the first ten years at work. Journal of Organizational Behavior, 23(6), 731-748. http://doi.org/10.1002/job.164

[83] Weng, Q., \& McElroy, J. C. (2012). Organizational career growth, affective occupational commitment and turnover intentions. Journal of Vocational Behavior, 80(2), 256-265. http://doi.org/10.1016/j.jvb.2012.01.014

[84] Juhdi, N., \& Hashim, J. (2013). Employability skills, job performance and promotability of employees working in SMEs Malaysia

[85] Wu, P.-C., \& Chaturvedi, S. (2009). The Role of Procedural Justice and Power Distance in the Relationship Between High-Performance Work Systems and Employee Attitudes: A Multilevel Perspective. Journal of Management, 35(5), 1228-1247. http://doi.org/10.1177/0149206308331097

[86] Rousseau, D. M. (1998). Invited Why workers still identify Essay with organizations. Journal of Organizational Behavior. http://doi.org/10.2307/3100169

[87] Ang, J. B., Banerjee, R., \& Madsen, J. B. (2013). Innovation and Productivity Advances in British Agriculture: 1620-1850. Southern Economic Journal, 80(1), 162-186. http://doi.org/10.4284/00384038-2011.239

[88] Shuck, B., \& Reio Jr, T. G. (2014). Employee engagement and well-being: A moderation model and implications for practice. Journal of Leadership \& Organizational Studies, 21(1), 43-58.

[89] Shahzad, K. (2011). Organizational environment, job satisfaction and career growth opportunities: a link to employee turnover intentions in public sector of Pakistan. Interdisciplinary Journal of Contemporary Research in Business (IJCRB), 2(9), 45-56.

[90] Weng, Q., \& McElroy, J. C. (2012). Organizational career growth affective occupational commitment and turnover intentions. Journal of Vocational Behavior, 80(2), 256-265. http://doi.org/10.1016/j.jvb.2012.01.014

[91] Wang, Q., Weng, Q., McElroy, J. C., Ashkanasy, N. M., \& Lievens, F. (2014). Organizational career growth and subsequent voice behavior: The role of affective commitment and gender. Journal of Vocational Behavior, 84(3), 431-441. http://doi.org/10.1016/j.jvb.2014.03.004

[92] Juhdi, N., \& Hashim, J. (2013). Employability skills, job performance and promotability of employees working in SMEs Malaysia.

[93] Juhdi, N., \& Hashim, J. (2013). Employability skills, job performance and promotability of employees working in SMEs Malaysia.

[94] SEIBERT, S. E., KRAIMER, M. L., \& CRANT, J. M. (2001) WHAT DO PROACTIVE PEOPLE DO? A LONGITUDINAL MODEL LINKING PROACTIVE PERSONALITY AND CAREER SUCCESS. Personnel Psychology, 54(4), 845-874. http://doi.org/10.1111/j.1744-6570.2001.tb00234.x

[95] Dries, N., Pepermans, R., \& Carlier, O. (2008). Career success Constructing a multidimensional model. Journal of Vocational Behavior, 73(2), 254-267. http://doi.org/10.1016/j.jvb.2008.05.005

[96] Weng, Q., McElroy, J. C., Morrow, P. C., \& Liu, R. (2010). The relationship between career growth and organizational commitment. Journal of Vocational Behavior, 77(3), 391-400. http://doi.org/10.1016/j.jvb.2010.05.003

[97] Weng, Q., McElroy, J. C., Morrow, P. C., \& Liu, R. (2010). The relationship between career growth and organizational commitment. Journal of Vocational Behavior, 77(3), 391-400. http://doi.org/10.1016/j.jvb.2010.05.003

[98] Hom, P. W., Tsui, A. S., Wu, J. B., Lee, T. W., Zhang, A. Y., Fu, P. P., \& Li, L. (2009). Explaining employment relationships with social exchange and job embeddedness. Journal of Applied Psychology, 94(2), 277-297. http://doi.org/10.1037/a0013453

[99] Juhdi, N., \& Hashim, J. (2013). Employability skills, job performance and promotability of employees working in SMEs Malaysia.

[100] Mitchell, T. R., \& Lee, T. W. (2001). 5. The unfolding model of voluntary turnover and job embeddedness: Foundations for a comprehensive theory of attachment. Research in Organizational Behavior, 23, 189-246. http://doi.org/10.1016/S01913085(01)23006-8

[101] Weng, Q., McElroy, J. C., Morrow, P. C., \& Liu, R. (2010) The relationship between career growth and organizational commitment. Journal of Vocational Behavior, 77(3), 391-400. http://doi.org/10.1016/j.jvb.2010.05.003

[102] Miao, Q., Newman, A., Schwarz, G., \& Xu, L. (2013). Participative Leadership and the Organizational Commitment of Civil Servants in China: The Mediating Effects of Trust in Supervisor.
British Journal of Management, 24(S1), S76-S92. http://doi.org/10.1111/1467-8551.12025

[103] Nouri, H., \& Parker, R. J. (2013). Career growth opportunities and employee turnover intentions in public accounting firms. The British Accounting Review, 45(2), 138-148. http://doi.org/10.1016/j.bar.2013.03.002

[104] Hackman, J. R., \& Oldham, G. R. (1975). Job satisfaction and job performance: A metaanalysis. Psychological Bulletin

[105] Bartlett, K. R. (2001). The relationship between training and organizational commitment: A study in the health care field. $\mathrm{Hu}$ man Resource Development Quarterly, 12(4), 335-352. http://doi.org/10.1002/hrdq.1001

[106] Weng, Q., McElroy, J. C., Morrow, P. C., \& Liu, R. (2010) The relationship between career growth and organizational commitment. Journal of Vocational Behavior, 77(3), 391-400. http://doi.org/10.1016/j.jvb.2010.05.003

[107] Blau, P. M. (1964). Justice in Social Exchange. Sociological Inquiry, 34(2), 193-206. http://doi.org/10.1111/j.1475682X.1964.tb00583.x

[108] Weng, Q., \& McElroy, J. C. (2012). Organizational career growth, affective occupational commitment and turnover intentions. Journal of Vocational Behavior, 80(2), 256-265. http://doi.org/10.1016/j.jvb.2012.01.014

[109] Malhotra, P., \& Singh, M. (2016). Indirect impact of high performers on the career advancement of their subordinates. Human Resource Management http://doi.org/10.1016/j.hrmr.2016.01.002

[110] Juhdi, N., \& Hashim, J. (2013). Employability skills, job performance and promotability of employees working in SMEs Malaysia.

[111] Miao, Q., Newman, A., Schwarz, G., \& Xu, L. (2013). Participative Leadership and the Organizational Commitment of Civil Servants in China: The Mediating Effects of Trust in Supervisor. British Journal of Management, 24(S1), S76-S92. http://doi.org/10.1111/1467-8551.12025 